\title{
SURVEY OF BLUEBERRY FARMS FOR BOTRYOSPHAERIA DIEBACK AND CROWN ROT PATHOGENS
}

\author{
J. SAMMONDS ${ }^{1}$, R. BILLONES ${ }^{1}$, M. ROCCHETTI ${ }^{3}$, H.J. RIDGWAY ${ }^{1}$, \\ M. WALTER ${ }^{2}$ and M.V. JASPERS ${ }^{1}$
}

\author{
${ }^{1}$ Faculty of Agriculture and Life Sciences, Lincoln University, Canterbury, \\ New Zealand \\ ${ }^{2}$ Plant \& Food Research, PO Box 51, Lincoln, New Zealand \\ ${ }^{3}$ New Zealand Gourmet Blueberries, PO Box 15045, Flaxmere, Hastings, \\ New Zealand
}

Corresponding author: Marlene.Jaspers@Lincoln.ac.nz

\begin{abstract}
Dieback and crown rot affect about $18 \%$ of blueberry plants in the main New Zealand production areas, costing about $\$ 500,000$ annually due to yield losses and replanting costs. Samples of symptomatic plants and stems were collected from six blueberry farms in the central North Island to determine which pathogens were responsible. From the 70 plants collected, numerous isolations from branch bases and tips, stem lesions and crowns revealed the apparent presence of Botryosphaeria species in 69\%, 64.5\%, $54.3 \%$ and $70 \%$ of samples respectively. These Botryosphaeria spp. were also found in a few roots and leaves but not fruit from symptomatic plants, nor in healthy asymptomatic stems. Morphological examination of conidia from 40 cultures identified B. lutea, B. parva, B. lutea/australis and B. obtusa with one unidentified Botryosphaeria species, apparently of the Neofusicoccum type. Molecular identification of 14 representative isolates from these 40 confirmed the presence of B. lutea, B. parva and B. australis. Keywords: blueberry, dieback, crown rot, Botryosphaeria, Neofusicoccum, Diplodia.
\end{abstract}

\section{INTRODUCTION}

Blueberries (Vaccinium corymbosum and V. ashei) were first introduced to New Zealand in 1950 by the Department of Agriculture, as they were considered a suitable crop for the peat-land around the Rakuhia Soil Research Station in the Waikato region (Toleman 1979). Commercial interest in the crop was initially slow to develop, with only 2 ha of plantings by 1974 (Langford 1982). However, rapid development of the industry took place in the late 1970 s when the agricultural sector was diversifying and export opportunities arose for blueberry. By June 2007 there were 560 ha managed by 95 growers, yielding 2940 tonnes, with crop values of NZ $\$ 25 \mathrm{~m}$ in the domestic market and NZ\$14.5m exported, mainly to the USA and Europe (FreshFacts 2007).

Stem canker and stem blight or dieback, caused by Botryosphaeria spp., are prevalent and destructive diseases of blueberry, particularly in south-eastern USA (Milholland \& Galletta1969). In New Zealand, blight of blueberry stems and plant crowns is increasingly becoming a problem in new production areas, such as Hawke's Bay, as well as in the traditional Waikato area. Newly established blueberry bushes ( $<2$ years old) can succumb to this disease, rapidly rendering the plantings worthless within a few years. Some estimates indicated that in Hawke's Bay approximately $18 \%$ of all plants are affected by stem canker/blight resulting in an annual cost of NZ\$500,000 due to yield loss and replanting costs (N. Patel, New Zealand Gourmet Blueberries, pers. comm.). The causal organisms for stem canker and stem blight in the USA were reported to be B. corticis 
(Milholland \& Galletta 1969) and B. dothidea (Witcher \& Clayton 1963), respectively, with the latter species being reported most commonly.

New Zealand growers have recently been beset by this disease, and although aware of Botryosphaeria spp. being associated with the dieback, needed confirmation of the particular species responsible (M. Rocchetti, New Zealand Gourmet Blueberries, pers. comm.). Earlier reports had identified pathogens of blueberry as $B$. dothidea (Johnston \& McKenzie 1982), B. parva (Pennycook \& Samuels 1985) and more recently B. stevensii (Young \& Fletcher 1997). New Zealand isolates of B. dothidea, B. parva and B. lutea from apple (Malus $X$ domestica) and kiwifruit (Actinidia deliciosa) (Pennycook \& Samuels 1985; Young \& Fletcher 1997) were also used in taxonomic studies of B. lutea, B. australis and B. dothidea (Slippers et al. 2004a, b). In addition, Botryosphaeria dieback of grapevines (Vitis vinifera) is relatively common in New Zealand, with the most prevalent species being B. lutea. B. parva, B. australis, B. stevensii and B. obtusa (anamorphs being Neofusicoccum luteum, N. parvum, N. australe, Diplodia mutila and $D$. seriata, respectively), with only rare isolation of $B$. dothidea (Baskarathevan et al. 2008).

The purpose of this study was to determine whether Botryosphaeria spp. were associated with blueberry wood tissues in plants that exhibited dieback and crown rot, and if so which species were responsible for the disease in New Zealand.

\section{MATERIALS AND METHODS}

Samples of 56 woody stems of blueberry ( $V$. corymbosum and $V$. ashei) plants that were dead or showing dieback, and 14 whole symptomatic plants were collected from six blueberry gardens, two each from the Hastings, Hamilton and Ohaupo regions, by Maurizio Rochetti of New Zealand Gourmet Blueberries. Of the 70 specimens, five gardens provided 10 symptomatic samples each and one garden provided 20 . The samples were sent to Lincoln University, where they were stored at $9^{\circ} \mathrm{C}$ until they could be assessed (within 4 weeks) by isolating from symptomatic tissues. With the branch samples, isolations were made from the base of each branch, from the edge of any cankers/lesions present, and from the tip of the branch if it displayed dieback. For the complete plants received, isolations were taken from the crown, at the edges of any lesions present and from a branch showing dieback (as before), resulting in 70 branches and 14 crowns sampled. A small number of isolations were also taken from the roots, leaves and fruit of symptomatic bushes, and from some asymptomatic, healthy branches on the same bushes. All material was washed, debarked, dipped in ethanol and flame-sterilised (I. Harvey, Plantwise, pers. comm.) before plating four pieces from each sample position onto potato dextrose agar (PDA; Oxoid) containing $0.25 \%$ chloramphenicol.

The isolation plates were incubated at $23^{\circ} \mathrm{C}$ until typical Botryosphaeria mycelium growth occurred, usually within 2-3 days. These fungi were sub-cultured onto prune agar (Leung et al. 1988) and placed under UV light at room temperature for 3-4 weeks to induce sporulation. From the 180 cultures obtained, 40 representative cultures were selected for morphological identification. Fresh subcultures of these were made on PDA and incubated in the dark at $25^{\circ} \mathrm{C}$ for 3 days to study mycelium colour and characteristics. The pycnidia that developed on prune agar were crushed to release the conidia, which were then identified according to their morphological features, length to width ratios, and 3-day colony characteristics (Phillips 2004).

This gave presumptive identification of all isolates, except $B$. obtusa whose identity could be confirmed by its characteristic conidia. From these 40 isolates, 14 representative isolates were selected for molecular identification. The DNA was extracted and amplified using the REDExtract-N-Amp ${ }^{\mathrm{TM}}$ Plant PCR Kit (Sigma-Aldrich, USA) by following the manufacturer's instructions. A mycelial scrape approximately $5 \mathrm{~mm}$ in diameter, taken from cultures that had been grown on PDA for 5 days, was used for extraction of the DNA. For identification by PCR-RFLP, a portion of the rDNA from each isolate was amplified using primers ITS1 (5'-TCCGTAGGTGAACCTGCGG-3') and NL4 (5'-GGTCCGTGTTTCAAGACGG-3') as described by Alves et al. (2005). Each 
PCR reaction consisted of $10 \mu \mathrm{l}$ REDExtract-N-Amp ${ }^{\mathrm{TM}}, 5$ pmoles of each primer, $4 \mu \mathrm{l}$ sterile distilled water and $4 \mu \mathrm{l}$ of DNA sample. The thermal cycle consisted of: initial denaturation of $5 \mathrm{~min}$ at $95^{\circ} \mathrm{C}$, followed by 30 cycles of $30 \mathrm{~s}$ at $94^{\circ} \mathrm{C}, 30 \mathrm{~s}$ at $50^{\circ} \mathrm{C}$ and $1 \mathrm{~min}$ at $72^{\circ} \mathrm{C}$, and a final extension period of $10 \mathrm{~min}$ at $72^{\circ} \mathrm{C}$. Once the thermal cycles were complete, $5 \mu \mathrm{l}$ of each PCR product was separated by electrophoresis in a $1 \%$ agarose gel in 1xTAE buffer. The gel was then stained with ethidium bromide and photographed on a UV transilluminator.

Restriction digestion was done as described by Alves et al. (2005) using the optimal conditions described by the enzyme manufacturers. To identify B. australis/B. lutea the amplified products were digested using the restriction endonuclease TaqI. To discriminate between $B$. australis and B. lutea, the products were also digested with SacII. To identify isolates of $B$. parva, the PCR products were digested with HaeIII. Fragments were separated by electrophoresis using a $1.5 \%$ agarose gel in 1xTAE buffer, which was then stained and photographed as for the PCR reaction. Species names were assigned by comparison with the published patterns of Alves et al. (2005).

\section{RESULTS}

Botryosphaeria-like isolates were recovered from all blueberry gardens, with incidence of stem samples from two gardens being $100 \%$, two other gardens being $90 \%$, one garden being $70 \%$ and another garden being $50 \%$. Sample positions were similar for presence of Botryosphaeria-like isolates, being $69 \%$ and $64.5 \%$, respectively, in the bases and tips of stems, and $54.3 \%$ and $70 \%$, respectively, in the stem lesions and crowns.

On symptomatic bushes, Botryosphaeria spp. were also found in roots and some leaves, but not in healthy asymptomatic branches or fruit (data not shown). Morphological identification of the 40 representative cultures selected from the 180 Botryosphaerialike isolates recovered, resulted in the identification of five Botryosphaeria species, comprising B. lutea (4), B. parva (21), B. lutea/australis (5; could not be differentiated morphologically), B. obtusa (1) and unidentified isolates (9) that all appeared to have conidia of the Neofusicoccum type. The identity of B. obtusa was confirmed by its characteristic conidia. Molecular identification of 14 representative isolates selected from the 40 identified by morphology [B. lutea $(\mathrm{n}=5)$, B. parva $(\mathrm{n}=4)$ and B. lutea/australis $(\mathrm{n}=5)$ ] confirmed the presumptive diagnoses, and showed that the five isolates from the B. lutea/australis group were B. australis (Fig. 1).

\section{DISCUSSION}

The high percentage of Botryosphaeria isolates obtained from symptomatic blueberry plants indicates that it is highly probable that at least four Botryosphaeria spp. are largely responsible for blueberry dieback and stem cankers in New Zealand. Similar symptoms in blueberry were shown by Koch's postulates to be caused by species of Botryosphaeria in the USA (Milholland \& Galletta 1969). Experiments to prove Koch's postulates with the New Zealand isolates are currently underway.

The species of Botryosphaeria responsible for similar symptoms in the USA, namely B. dothidea and B. corticis (Ballington et al. 1993; Milholland \& Galletta 1969; Witcher \& Clayton 1963) were not identified in this study. However, since many Botryosphaeria spp. are cosmopolitan in their host ranges (Pennycook \& Samuels 1985; Young \& Fletcher 1997; Slippers et al. 2004a, b; Baskarathevan et al. 2008), inoculum from adjoining crops, such as grapevines, kiwifruit and apples, may have colonised the blueberry gardens. In addition, the identification of these blueberry pathogens in the USA was done in the 1960s and was largely dependent upon morphological features of conidia of Botryosphaeria species, such as size, colour, septation and wall characteristics of thickness and texture. These characteristics have more recently been shown to be unreliable as they frequently overlap and also change over time (Zhou \& Stanosz 2001). Slippers et al. (2004a) deduced that "the genus Botryosphaeria remains in taxonomic disarray" and subsequently used multiple gene genealogies and phenotypic characters to differentiate several species previously identified as B. dothidea. A comparison 

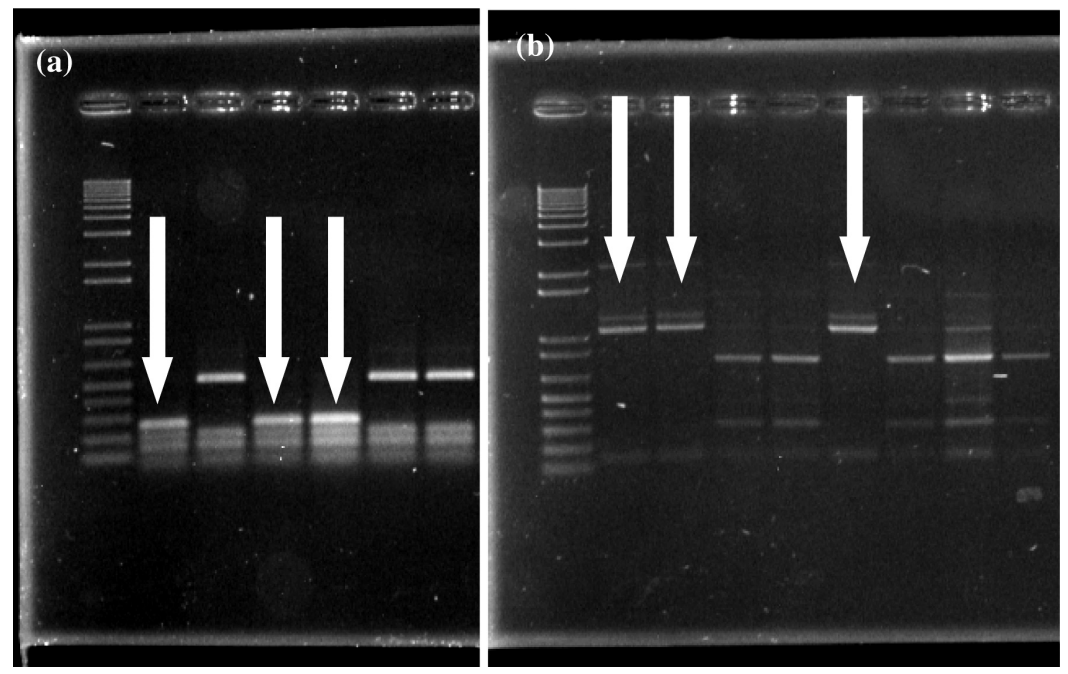

FIGURE 1: Representative agarose gels showing RFLP patterns for Botryosphaeria spp. isolates from diseased blueberry plants and a $1 \mathrm{~kb}+$ DNA ladder (Invitrogen) in the left hand lane. (a) Hae III digest, which identified $B$. parva (arrows) as being distinct from the other lanes representing other Botryosphaeria species. (b) SacII digest, which discriminated between B. lutea (arrows) and B. australis.

should be made between the New Zealand isolates and the USA isolates of $B$. dothidea and $B$. corticis, which have very similar conidia to those of the B. lutea, B. parva and B. australis identified in this study. The study should also use molecular methods, such as those used by Alves et al. (2005) and Zhou \& Stanosz (2001), which were able to distinguish between Botryosphaeria taxa and related species, including $B$. dothidea, B. corticis, B. obtusa, B. lutea and B. parva.

This survey has demonstrated that the damaging dieback and crown rot of blueberries, which is reported to cause significant economic losses in North Island crops, is associated with the same Botryosphaeria species that cause dieback in grapevines (Baskarathevan et al. 2008) and fruit rots of apple and kiwifruit (Pennycook \& Samuels 1985; Young \& Fletcher 1997). The current knowledge on epidemiology of the disease in grapevines may be useful to developing an understanding of the similar disease in blueberries. However, fundamental research is required to improve understanding of the blueberry disease cycle so that strategic disease management protocols may be developed. The relatively successful disease resistant breeding programmes implemented in the USA (Ballington et al. 1993) should also be considered as a potential control strategy. To date New Zealand blueberry breeding programmes have focussed on improving yield, fruit quality and ripening. Disease and pest resistance was not selected for because blueberries were considered to be relatively free of major pests and diseases (Patel \& George 1997), which is clearly not the case now.

\section{ACKNOWLEDGEMENTS}

The authors are grateful to Gourmet Blueberries Ltd and Blueberries New Zealand for jointly funding the summer scholarship that allowed Jackie Sammonds to complete this study. 


\section{REFERENCES}

Alves A, Phillips AJL, Henriques I, Correia A 2005. Evaluation of amplified ribosomal DNA restriction analysis as a method for identification of Botryosphaeria species. FEMS Microbiology Letters 245: 221-229.

Ballington JR, Rooks SD, Milholland RD, Cline WO, Meyers JR 1993. Breeding blueberries for pest resistance in North Carolina. Acta Horticulturae 346: 87-94.

Baskarathevan J, Jaspers MV, Jones EE, Ridgway HJ 2008. Distribution of Botryosphaeria species causing grapevine dieback and decline in New Zealand vineyards. New Zealand Plant Protection 61: 392 (Abstract only).

FreshFacts 2007. http://www.hortresearch.co.nz/files/aboutus/factsandfigs/ff2007.pdf (retrieved 16 February 2009).

Langford G 1982. A review of the New Zealand blueberry industry. MAF Advisory Services Report June 1982, Lincoln, New Zealand. 44 p.

Leung H, Borrmeo ES, Bernardo MA, Notteghem JL 1988. Genetic analysis of virulence in the rice blast fungus Magnaporthe grisea. Phytopathology 78: 1227-1233.

Johnston PR, McKenzie EHC 1982. Blueberry diseases in New Zealand. New Zealand Journal of Experimental Agriculture 10: 73-77.

Miller SA, Patel N, Stanley CJ 2006. Cranberry pests and diseases in New Zealand. VIIIth International Symposium on Vaccinium Culture. ISHS Acta Horticulturae 715: 509-512.

Milholland RD, Galletta GJ 1969. Pathogenic variation among isolates of Botryosphaeria corticis on blueberry. Phytopathology 59: 1540-1543.

Patel N, George JP 1997. Progress with breeding blueberries in New Zealand. VIth International Symposium on Vaccinium Culture. ISHS Acta Horticulturae 446: 149-153.

Pennycook SR, Samuels GJ 1985. Botryosphaeria and Fusicoccum species associated with ripe fruit of Actinidia deliciosa (kiwifruit) in New Zealand. Mycotaxon 24: 445-458.

Phillips AJL 2004. http://www.crem.fct.unl.pt/botryosphaeria_site/ (retrieved 10 February 2009).

Slippers B, Crous PW, Denman S, Coutinho TA, Wingfield BD, Wingfield MJ 2004a. Combined multiple gene genealogies and phenotypic characters differentiate several species previously identified as Botryosphaeria dothidea. Mycologia 96: 83-101.

Slippers B, Fourie G, Crous PW, Coutinho TA, Wingfield BD, Wingfield MJ 2004b. Multiple gene sequences delimit Botryosphaeria australis sp. nov. from B. lutea. Mycologia 96: 1030-1041.

Toleman EE 1979. Blueberry production. New Zealand. Agricultural Science 13(3): 127-133.

Witcher W, Clayton CN 1963. Blueberry stem blight caused by Botryosphaeria dothidea (B. ribis). Phytopathology 53: 705-712.

Zhou S, Stanosz GR 2001. Primers for amplification of $\mathrm{mt}$ SSU rDNA, and a phylogenetic study of Botryosphaeria and associated anamorphic fungi. Mycological Research 105: 1033-1044.

Young JM, Fletcher MJ 1997. International Collection of Micro-organisms from Plants http://www.landcareresearch.co.nz/research/biosystematics/fungi/icmp97.pdf (retrieved 18 April 2009). 